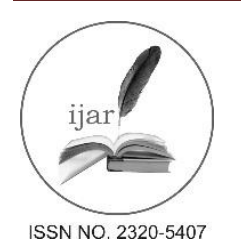

Journal homepage:http://www.journalijar.com

Journal DOI:10.21474/IJAR01

INTERNATIONAL JOURNAL

OF ADVANCED RESEARCH

RESEARCH ARTICLE

\title{
RAPID SIMPLIFIED PROTOCOL FOR PURIFICATION OF TAQ DNA POLYMERASE FRAGMENT EXPRESSED IN ESCHERICHIA COLI.
}

\author{
*Raghu $\mathbf{N}^{1}$ and Deepak $\mathbf{J}^{2}$. \\ 1. Department of Biotechnology, Centre for Molecular and Cellular Biology, School of life Sciences, Manipal \\ University, Manipal, India. \\ 2. Department of Biochemistry, Bharathiar University, Coimbatore, India.
}

\section{Manuscript Info}

Manuscript History:

Received: 12 April 2016

Final Accepted: 19 May 2016

Published Online: June 2016

Key words:

Taq DNA polymerase, E. coli, BL21 (DE3), enzyme activity.

*Corresponding Author

Raghu N.

\begin{abstract}
An economical and simple method, boiling lysis method was developed and used to purify $94 \mathrm{kDa}$ Taq DNA polymerase fragment from transformed BL21 (DE3) cells. It is based on conditions such as thermostable properties, boiling time, removal of nucleic acids to achieve a high yield and activity of Taq DNA polymerase fragment on one cycle of boiling for $60 \mathrm{mins}$. The centrifugation protocol followed was ideal for the purification, followed by streptomycin sulphate treatment to remove nucleic acids. The clear supernatant containing heat resistant Taq DNA polymerase was separated and stored at $-70^{\circ} \mathrm{C}$. The activity of enzyme was compared with commercial Taq DNA polymerase, stored in buffer containing $50 \%$ glycerol, at $-20^{\circ} \mathrm{C}$. The purified enzyme has a molecular weight of $94 \mathrm{kDa}$, as predicted by SDSPAGE and yielded appropriate enzyme activity comparing to the commercial Taq DNA polymerase. The whole process of purification was achieved within $3 \mathrm{hrs}$. A total $53 \mathrm{mg}$ of Taq DNA polymerase enzyme was purified from 1 liter of bacterial culture emphasizing the fact that our method was economical and simple.
\end{abstract}

Copy Right, IJAR, 2016. All rights reserved.

\section{Introduction:-}

Taq DNA polymerase is an enzyme procured from an heat stable bacteria called Thermus aquaticus having a molecular weight of 94,000 Daltons $^{1}$.Taq polymerase is the most commonly used enzyme in almost every biological sciences research laboratory around the globe for the past three decades ${ }^{2,3}$. This powerful tool for amplification of DNA has seen a major breakthrough in its isolation, modification, purification, and activity ${ }^{3}$. A lot of work done in this aspect even today for better exploitation of this enzyme for commercial usage ${ }^{4}$. Many articles have described purification methods for Taq DNA polymerase ${ }^{5,6}$, purification of biologically active enzyme from complex mixture remains as one of the most challenging aspect in biotechnology. Previously published protocols involves use of large starting culture volumes and use of complex buffers containing many detergents ${ }^{7}$. By addressing these issues we have developed simple and rapid purification protocol which can be carried out in labs that lacks some of the reagents and equipment required in original protocol. Boiling lysis and nucleic acid removal methods yielded an approx 53mg of Taq enzyme within 3hrs from 1-liter Escherichia coli cell culture. The scale-down, simplified, rapid method described here would enable Taq DNA polymerase purification more feasible for research and diagnostic laboratories.

\section{Materials and method:-}

\section{Enzyme purification:-}

The colony-transformed BL21 cells were cultured overnight at $37^{\circ} \mathrm{C}$ in $5 \mathrm{ml}$ of LB (Luria-Bertani) (Titan Biotech, India) medium supplemented with ampicillin $(100 \mu \mathrm{g} / \mathrm{ml})$ (HiMedia, India). Large scale cultures were then initiated 
by adding $5 \mathrm{ml}$ of overnight culture to $100 \mathrm{ml}$ of LB medium with the addition of ampicillin $(100 \mu \mathrm{g} / \mathrm{ml})$. These cultures were grown at $37^{\circ} \mathrm{C}$ until the broth had reached an attenuance $\left(\mathrm{D}_{600}\right)$ of 0.6. At this point, IPTG was added to a concentration of $0.5 \mathrm{mM}$ and the culture was grown for another 12-18h. The bacterial cells were harvested by centrifugation for $10 \mathrm{~min}$ at $8000 \mathrm{~g}$, then resuspended in $4 \mathrm{X}$ Taq storage buffer $(20 \mathrm{mM}$ Tris/HCL), $\mathrm{pH} 8.0,10 \mathrm{mM}$ EDTA, $100 \mathrm{mM} \mathrm{KCL}, 0.5 \%$ Nonidet P40 and $0.5 \%$ Tween 20) to one-twentieth of the original volume by vigorous vortex-mixing. Suspension of cells was disrupted by sonication on ice (5mins, 10-S pulse with 10-S pause intervals) and centrifuged at $12000 \mathrm{~g}, 15 \mathrm{mins}, 4^{\circ} \mathrm{C}$. The supernatant was incubated at $75^{\circ} \mathrm{C}$ for $1 \mathrm{~h}$, cooled on ice for $10 \mathrm{~min}$, centrifuged at $13000 \mathrm{~g}, 15 \mathrm{~min}, 4^{\circ} \mathrm{C}$ to remove the denatured proteins. Nucleic acids was removed by addition of streptomycin sulfate solution $(40 \%)$ to a final concentration of $4 \mathrm{mg} / \mathrm{ml}$. The mixture was gently stirred for $1 \mathrm{~h}$ at $4^{0} \mathrm{C}$ and centrifuged at $13000 \mathrm{~g}, 15 \mathrm{~min}, 4^{\circ} \mathrm{C}$. The purified Taq polymerase fragment was then stored at $-20^{\circ} \mathrm{C}$. It required proper and careful diluted before use.

\section{Protein estimation and activity assay:-}

The Taq Protein concentration was determined by measuring $\mathrm{A}_{595}$ as described by Bradford ${ }^{8}$. The Taq protein content was qualitatively visualized by SDS-PAGE on denaturing polyacrylamide gel $[4.5 \%(\mathrm{w} / \mathrm{v})$ stacking gel $12 \%$ $(\mathrm{w} / \mathrm{v})$ separating gel] stained with coomassie brilliant blue by loading $10 \mu \mathrm{l}$ aliquot of the supernatant containing Taq protein after nucleic acid treatment.

The activity of the purified Taq DNA polymerase fragment was determined using a PCR amplification assay by titration against the commercial enzyme preparation (Fermentas, Pittsburgh, United States). For the enzyme activity assay, the purified Taq polymerase was diluted 1:10, 1:20, and 1:30 with $1 \mathrm{X}$ Taq storage buffer before adding it to the reaction mixtures. Titration of the enzyme was performed in $50 \mu$ reaction mixtures with $0.5 \mu$ l of diluted enzyme added immediately before starting the temperature cycling. The reaction mixture contained $75 \mu \mathrm{M}$ of each dNTP (NEB), $2.5 \mathrm{mM} \mathrm{MgCl}_{2}, 0.02 \mu \mathrm{M}$ each of Upstream and Downstream Primers (Sigma Aldrich, Bengaluru), (5'GATGTTGATGCCGACAAATG-3' and 5'-ACCATAGCCAGGTTGTTTGC-3') that amplifies a 615-bp fragment of the chuA gene encoding outer membrane heme/hemoglobin receptor, and 100ng of template DNA isolated from uropathogenic E. coli culture in 1X PCR reaction buffer $1 \mathrm{X}$ Taq Buffer containing $(42.5 \mathrm{mM}$ Tris- $\mathrm{HCl}(\mathrm{pH} 8.2$ at $\left.25^{\circ} \mathrm{C}\right), 50 \mathrm{mM} \mathrm{KCl}, 20 \mathrm{mM}\left(\mathrm{NH}_{4}\right)_{2} \mathrm{SO}_{4}, 0.08 \%$ (v/v) Nonidet P-40, $0.01 \%$ (v/v) Tween 20), 2.5 units of Taq DNA polymerase (Bhat Biotech India Pvt Ltd, Bengaluru). PCR amplification was started and was run for 30 cycles under the conditions of $3 \mathrm{~min}$ at $95^{\circ} \mathrm{C}, 30 \mathrm{sec}$ at $94^{\circ} \mathrm{C}, 30 \mathrm{sec}$ at $57^{\circ} \mathrm{C}, 30 \mathrm{sec}$ at $72^{\circ} \mathrm{C}$ and final extension $10 \mathrm{~min}$ at $72^{\circ} \mathrm{C}$ in an DNAmp (Bhat Biotech India Pvt Ltd, Bengaluru) thermo cycler. After PCR cycle was completed, aliquots of $10 \mu \mathrm{l}$ of PCR products were analyzed by electrophoresis in $1.5 \%(\mathrm{w} / \mathrm{v})$ agarose gel in the presence of TAE (Tris/acetate/EDTA) buffer. Proteins were stained with $5 \mathrm{ng} / \mu \mathrm{l}$ propidium iodide and a SM0311 ladder (Fermentas) was used as a size marker. To test the ability of the purified Taq enzyme to amplify different lengths of DNA sequences, the enzyme was applied to amplify $615 \mathrm{bp}$ and $246 \mathrm{bp}$ fragments.

\section{Results:-}

In our experiment, one cycle treatment consisted of $60 \mathrm{~min}$ boiling lysis and subsequent centrifugation at $12000 \mathrm{~g}$ for $15 \mathrm{~min}$ at $4^{\circ} \mathrm{C}$. As demonstrated in Figure 1, Taq polymerase was released in high yield in the supernatant after boiling (total period of $60 \mathrm{~min}$ ). The figure also indicates that almost no other protein remained in the supernatant after boiling.

To check for contamination with nucleic acids, $3 \mu 1$ of boiled lysate supernatant was tested on agarose gel electrophoresis, as shown in Figure 2. Using our protocol, the Taq preparations showed the presence of nucleic acid unless the streptomycin treatment was used (lane 1-2 in Figure 2). To remove this nucleic acid contamination, the enzyme was treated with streptomycin sulphate solution (40\%) to a final concentration of $4 \mathrm{mg} / \mathrm{ml}$. The mixture was gently stirred for $1 \mathrm{~h}$ at $4^{\circ} \mathrm{C}$ and centrifuged at $12000 \mathrm{~g}$ for $15 \mathrm{~min}$ at $4^{\circ} \mathrm{C}$. The supernatant was stored at $-20^{\circ} \mathrm{C}$ for several months. This step was completely effective in the removal of nucleic acid contamination (see lane 3-4 in Figure 2).

The activity of the purified Taq DNA fragment was quantified by a PCR-amplification reaction titrated against commercial enzyme (Figure 3). The concentration of $2 \mu \mathrm{l}$ of product of the $0.6 \mathrm{~kb}$ fragment amplified using 1:10diluted Taq polymerase (lane 10) was nearly equivalent to that of $2 \mu l$ of product amplified using commercial enzyme (lane 1). Thus the 1:10 diluted Taq enzyme showed double activity compared with the commercial enzyme (Figure 3). The 1:30 diluted Taq enzyme prepared using our protocol showed an activity of 4units/ $\mu$ l. Consequently, the activity of the typical concentration of the final purified fragment of undiluted stocks reached a value of 40 
units/ $\mu 1$. In the present study, 1 litre of bacterial cultures may produce amounts of Taq polymerase that is equivalent to $1.06 \times 10^{7}$ units, a value in contrast with that pertaining to the commercial enzyme. We also confirmed that at a of 1:30 dilution Taq obtained by our method showed an equivalent activity with that of commercial enzyme. We concluded that the activity value of 1 unit quantified by PCR assay contained the equivalent of 3.8ng of active Taq protein, as verified by the Bradford method $(0.38 \mathrm{mg} / \mathrm{ml},-$ (undiluted)).

To confirm the effectiveness of the Taq enzyme purified by our protocol, we tested the ability of the enzyme to amplify different length of DNA sequences (Figure 4). When 1:30 dilutions of purified Taq enzyme and commercial enzyme (Fermentas, Pittsburgh, United States) were used to amplify DNA fragments of lengths 615bp and 246bp under the same conditions, results indicated that the purified Taq enzyme performed with an efficiency equivalent to that of the commercial enzyme.

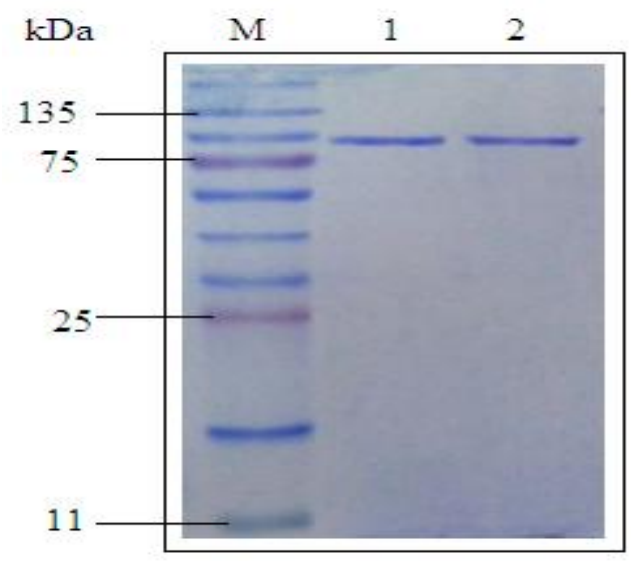

Figure 1:- Assessment of Taq DNA fragment by SDS/12\%-PAGE with Coomassie Blue staining when boiling cycle were applied. Lane M contains protein marker, Lane 1 and 2 show the Taq protein in the supernatant after

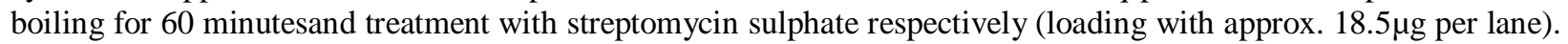
The expected Taq DNA polymerase $(94 \mathrm{kDa})$ was released with high yield and purity after boiling, streptomycin treatment and centrifugation.

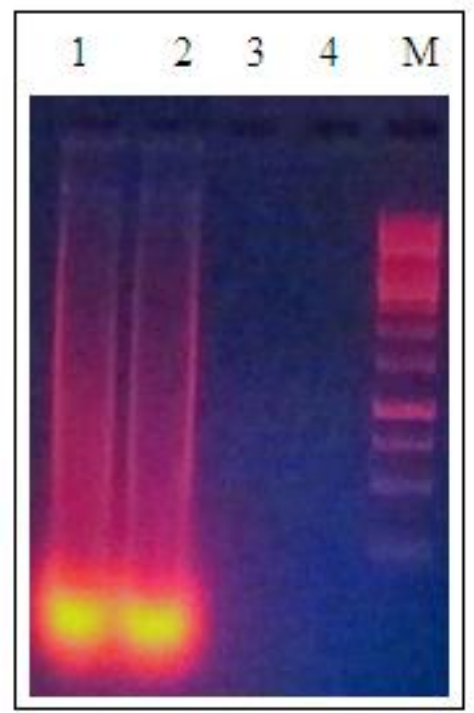

Figure 2:- Identification of the nucleic acid contamination in the supernatant of boiled lysate with or without streptomycin sulphate treatment. Lane M contained 100bp (Fermentas) marker. Lanes 1-2 show the presence of nucleic acid contamination with one cycle boiling and centrifugation. Lane 3-4 indicates the absence of nucleic acids in the supernatant extracted using the streptomycin sulphate treatment. 


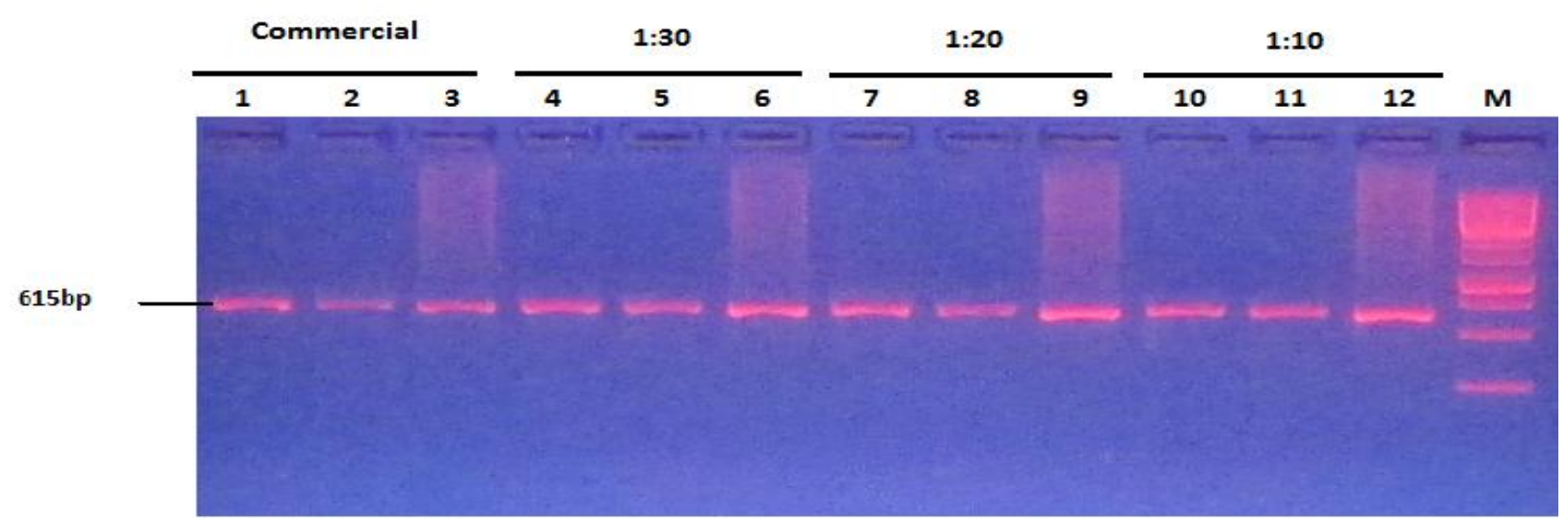

Figure 3:- PCR amplification of $C h u A$ gene using the purified Taq polymerase in different dilutions $(1: 10,1: 20$ and 1:30). The expected amplified DNA fragment is marked with an arrow. Lane 1-12 shows the amplification products using commercial enzyme and Taq polymerase purified using our method. A $2 \mu$ portion of PCR products was loaded in lanes 1,4,7, and 10, a $3 \mu \mathrm{l}$ portion in lanes 2,5,8 and 11, and a $5 \mu 1$ portion in lanes 3,6,9, and 12 .

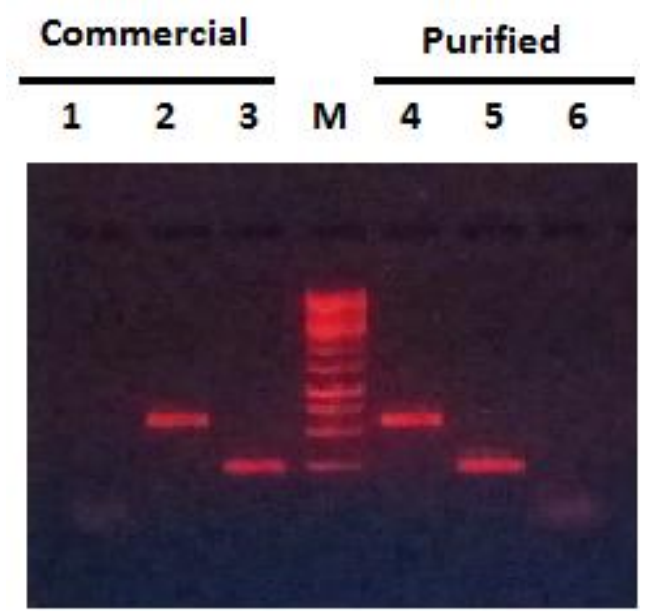

Figure 4:- PCR amplification of different lengths of DNA fragment using the commercial enzyme and purified Taq polymerase. Lane M contains SM0311 Marker. Lanes 2 and 4 show the amplification products of the chuA gene (615bp), lanes 3 and 5 show the products of the chuA gene (246bp), Lanes 1 and 6 are negative controls.

\section{Discussion:-}

Inventions in the field of molecular biology in present era especially the isolation \& purification of enzymes is at the rate of minutes. New protocol for isolation and purification of commercially important enzymes is designed and developed across the globe every minute. With high speed technologies, research in PCR application and DNA sequencing techniques based on the use of Taq DNA polymerase, many protocols have been followed for purification of this enzyme to meet the current research and commercial requirements. Of them, most commonly used are heat treatment and freeze thawing. Unfortunately all these methods involves complex processes, which are time consuming and requiring sophisticated laboratories, in addition to the use of expensive and toxic chemicals. In the current study we formulated a simple protocol for the purification of full length Taq polymerase enzyme using boiling lysis method, which is based on its thermostability. Our experimentation for enzyme purification takes only 2-3hrs, using only one kind of storage buffer, no specialized instrumentation required nor usage of toxic chemicals. In our experiments, we isolated and purified $53 \mathrm{mg}$ of Taq polymerase enzyme from one liter of crude bacterial culture. The activity of our isolated enzyme was found to be $1.8 \times 10^{7}$ units $/ \mathrm{ml}$ as assessed and confirmed by PCR assay and the yield was compared with $5 \mathrm{U} / \mu \mathrm{l}$ (Fermentas) of Taq DNA polymerase. 


\section{Acknowledgments:-}

We thank Dr. Venkat Raman, Dept. of Biotechnology, Dayanand Sagar College, Bangalore, for providing the Taq clone.

\section{References:-}

1. Lawyer FC, Stoffel S, Saiki RK, Myambo K, Drummond R Gelfand DH, Isolation, characterization, and expression in Escherichia coli of the DNA polymerase gene from Thermus aquaticus, J Biol Chem, 264(1989) 6427-6437.

2. Mullis KB \& Faloona FA, Specific synthesis of DNA in vitro via a polymerase-catalyzed chain reaction. Methods Enzymol. 87 (1987) 55023-6.

3. Saiki RK, Gelfand DH, Stoffel S, Scharf SJ, Higuchi R, Horn GT, Mullis KB\&Erlich HA, Primer-directed enzymatic amplification of DNA with a thermostable DNA polymerase,Science, 239(1988) 487-491.

4. Lawyer FC, Stoffel S, Saiki RK, Chang SY, Landre PA, Abramson RD\& Gelfand DH High-level expression, purification, and enzymatic characterization of full-length Thermus aquaticus DNA polymerase and a truncated form deficient in 5' to 3' exonuclease activity,Genome Res, 2(1993) 275-287.

5. Pluthero F G, Rapid purification of high-activity Taq DNA polymerase, Nucleic Acids Research, (1993) 4850 4851.

6. Grimm E \& ArbuthnotP, Rapid purification of recombinant Taq DNA polymerase by freezing and high temperature thawing of bacterial expression cultures, Nucleic Acids Res, 23(1995) 4518-4519.

7. Engelke DR, Krikos A, Bruck ME \& Ginsburg D, Purification of Thermus aquaticus DNA polymerase expressed in Escherichia coli. Anal Biochem, 191(1990) 396-400.

8. Harlow E\& Lane D, Bradford assay. CSH Protoc,6 (2006) 1-4. 